\title{
Serological detection and risk factors for equine piroplasmosis in the semiarid region of Pernambuco, Northeastern Brazil
}

\author{
Detecção sorológica e fatores de riscos para piroplasmose equina na região semiárida de Pernambuco, \\ Nordeste do Brasil \\ Eline Almeida Rodrigues de Souza ${ }^{1}$; Andreina de Carvalho Araujo ${ }^{2}$; Larissa Célly Souza Regis Pires ${ }^{1}$; \\ Carla Roberta Freschi; Sergio Santos Azevedo ${ }^{4}$; Rosangela Zacarias Machado ${ }^{3}$; Maurício Claudio Horta ${ }^{1 *}$ \\ ${ }^{1}$ Laboratório de Doenças Parasitárias, Universidade Federal do Vale do São Francisco - UNIVASF, Petrolina, PE, Brasil \\ ${ }^{2}$ Universidade Federal de Minas Gerais - UFMG, Belo Horizonte, MG, Brasil \\ ${ }^{3}$ Faculdade de Ciências Agrárias e Veterinárias - FCAV, Universidade Estadual Paulista Júlio de Mesquita Filho - UNESP, Jaboticabal, \\ SP, Brasil \\ ${ }^{4}$ Unidade Acadêmica de Medicina Veterinária, Universidade Federal de Campina Grande - UFCG, Patos, PB, Brasil
}

Received July 15, 2019

Accepted September 26, 2019

\begin{abstract}
Equine piroplasmosis, an economically important disease in horses, has so far not been reported in Pernambuco state, Brazil. This study aimed to evaluate the seroprevalence of anti-Babesia caballi and anti-Theileria equi antibodies based on the detection of these agents in equine blood and in ticks on horses in the municipality of Petrolina, Pernambuco, northeastern Brazil. Blood samples were drawn from 393 horses and sera were examined by ELISA. The presence of tick infestations was evaluated, and 101 ticks were subjected to DNA amplification for the detection of Babesia spp. by polymerase chain reaction (PCR). No parasites were detected in the blood smears. Anti-B. caballi and anti-T. equi antibodies were found in 27.2\% (107/393) and 34.8\% (137/393) horses, respectively. Infestation by Dermacentor nitens was detected in $4.3 \%$ (17/393) of the horses. There was no DNA amplification of the agents in ticks. The risk factors for the presence of anti-T. equi antibodies $(P<0.05)$ were: purebred $(P<0.001)$, animals older than 156 months $(P=0.014)$, and the presence of ticks $(P=0.001)$. No risk factors for $B$. caballi were identified. This study confirmed the circulation of agents of equine piroplasmosis in the municipality of Petrolina, state of Pernambuco, Brazil.
\end{abstract}

Keywords: Babesia caballi, Theileria equi, horse, diagnostic, ELISA, PCR.

\section{Resumo}

Piroplasmose equina é uma doença economicamente importante em equinos e não possui relatos no Estado de Pernambuco, Brasil. O objetivo deste estudo foi avaliar a soroprevalência de anticorpos anti- $B$. caballi e anti-T. equi pela detecção destes agentes no sangue e carrapatos de equinos no município de Petrolina, Pernambuco, Nordeste do Brasil. Amostras de sangue de 393 equinos foram coletadas e submetidas ao esfregaço sanguíneo e ELISA. A presença de infestaçáo por carrapatos foi avaliada, e 71 carrapatos foram submetidos à Reação em Cadeia da Polimerase (PCR) para Babesia spp. Nenhum parasito foi detectado na análise de esfregaços de sangue. Anticorpos anti-B. caballi e anti-T. equi foram verificados em 27,2\% (107/393) e 34,8\% (137/393) dos equinos, respectivamente. A infestação por Dermacentor nitens foi verificada em 4,3\% (17/393) dos equinos. Não houve amplificação do DNA dos agentes nos 71 carrapatos submetidos à PCR. Os fatores de risco para presença de anticorpos anti-T. equi $(P<0,05)$ foram: raça definida $(P<0,001)$, animais $>$ de 156 meses $(P=0,014)$ e presença de carrapatos $(P=0,001)$. Nenhum fator de risco foi identificado para $B$. caballi. Esse estudo permitiu a confirmação da presença de agentes da piroplasmose equina no município de Petrolina, Pernambuco.

Palavras-chave: Babesia caballi, Theileria equi, equinos, diagnóstico, ELISA, PCR.

\footnotetext{
*Corresponding author: Maurício Claudio Horta. Laboratório de Doenças Parasitárias, Universidade Federal do Vale do São Francisco - UNIVASF, Rodovia BR-407, Km 12, Lote 543, s/n, Projeto de Irrigação Nilo Coelho, CEP 56300-000, Petrolina, PE, Brasil. e-mail: horta.mc@hotmail.com
} 


\section{Introduction}

Equine piroplasmosis is an important tick-borne disease caused by the intraerythrocytic protozoan parasites Theileria equi and/or Babesia caballi, which affect wild and domesticated equids (WISE et al., 2014). In Brazil, T. equi and B. caballi are transmitted mainly by Rhipicephalus microplus and Dermacentor nitens, respectively. Amblyomma cajennense has also been associated with the transmission of T. equi (KERBER et al., 2009). These agents can also be transmitted transplacentally (SANTOS et al., 2008), as well as iatrogenically through blood transfusions and the use of contaminated needles, nasogastric tubes and endoscopes (WISE et al., 2014).

The disease is considered endemic in tropical, subtropical and temperate regions (BRÜNING, 1996; KAPPMEYER et al., 2012; AHARONSON-RAZ et al., 2014). It is on the list of notifiable diseases, so infected animals are subject to international travel restrictions (OIE, 2018a), causing problems to the horse industry (VIEIRA et al., 2018). Clinical signs of the disease, which may range from asymptomatic to acute, are characterized by fever, jaundice, intravascular hemolysis based on free hemoglobin in the blood, anemia, hemoglobinuria, edema, bilirubinuria, azotemia, acute renal failure, depression, hepatomegaly, splenomegaly, and lymphadenopathy (DE WAAL, 1992; GUIMARÃES et al., 1998; MEHLHORN \& SCHEIN 1998; WISE et al., 2013; ADAM et al., 2017). However, obvious signs of the disease are often absent common, making it difficult for regions to remain free of the agent. Animals infected with T. equi can manifest the disease after stress, strenuous exercise, immunosuppression and the administration of steroids (WISE et al., 2014).

Serological studies on B. caballi and T. equi have been conducted in the south, southeast and central-west regions of Brazil, which have revealed B. caballi prevalence rates varying from 18 to $90 \%$ (BARBOSA et al., 1995; HEUCHERT et al., 1999; HEIM et al., 2007; KERBER et al., 2009; VIEIRA et al., 2013; NOGUEIRA et al., 2017; BRAGA et al., 2017) and T. equi prevalence rates from 17 to $100 \%$ (TENTER \& FRIEDHOFF, 1986; BARBOSA et al., 1995; RIBEIRO et al., 1999; HEUCHERT et al., 1999; XUAN et al., 2001; HEIM et al., 2007; GOLYNSKI et al., 2008; KERBER et al., 1999, 2009; BALDANI et al., 2010; SALVAGNI et al., 2010; VIEIRA et al., 2013; PROCHNO et al., 2014; VIEIRA et al., 2015, 2018; FERREIRA et al., 2016; GUIMARÁES et al., 2016; BRAGA et al., 2017; SCHEIN et al., 2018). However, such studies have rarely been carried out in northeastern Brazil. Specifically in the state of Pernambuco, B. caballi and T. equi infections in horses have so far not been reported, and little is known about the epidemiology of these agents. Therefore, the purpose of this study was to determine the seroprevalence of $B$. caballi and T. equi in horses and to perform PCR assays on ticks found on the horses in the municipality of Petrolina, Pernambuco, northeastern Brazil.

\section{Materials and Methods}

\section{Study area and sampling}

This study was carried out from December 2011 to May 2012 in rural and urban areas in the municipality of Petrolina, situated in the semiarid region of the São Francisco Valley, which covers an area of $4,558.537 \mathrm{~km}^{2}$ in the state of Pernambuco. For this study, 393 horses were randomly selected, regardless of sex, breed or age. Samples to be evaluated were determined considering an estimated prevalence of $50 \%$, a confidence interval of $95 \%$ and an absolute precision of $7 \%$.

Blood samples were drawn by jugular venipuncture into vacutainer tubes with and without anticoagulant. Tubes without anticoagulant were kept at room temperature until clot retraction occurred. After retraction, the blood samples were centrifuged $(3,000 \mathrm{~g}, 10 \mathrm{~min})$ to obtain serum, which was then stored at $-20^{\circ} \mathrm{C}$. The ticks parasitizing the horses were removed with anatomical tweezers, placed in tubes containing 70\% ethanol solution and identified as described by Aragão \& Fonseca (1961).

This study was approved by the Human and Animal Ethics Committee of the Federal University of Vale do São Francisco, under Protocol No. 0011/261011.

\section{Blood smears}

Immediately after drawing blood without anticoagulant, blood smears were prepared and stained using fast staining kits (Fast Panoptic, RENYLAB ${ }^{\circledR}$ ). The blood smears were examined under a light microscope equipped with a $10 \mathrm{x}$ eyepiece and an immersion objective lens $(1000 \mathrm{x})$ for hemoprotozoan examination.

\section{Enzyme-linked Immunosorbent Assay (ELISA)}

Serum samples were diluted by a factor of 1:100 and subjected to ELISA for the detection of anti-B. caballi and anti-T. equi antibodies, as described by Baldani et al. (2004). This test involved the use of purified antigens of $B$. caballi and T. equi, alkaline phosphatase conjugated anti-horse IgG (Sigma Chemical Co., code A6063) diluted by a factor of 1:15000 in PBS-Tween-80 with $5 \%$ skim milk powder and $10 \mathrm{mg}$ of pNPP (p-nitrophenyl phosphate) substrate. Optimal reactivity levels of $B$. caballi and T. equi antigens were 2.5 and $10 \mu \mathrm{g} / \mathrm{mL}$, respectively. The reaction was detected in a microplate reader (Microplate Reader MRX TC Plus, Dynex Technology, USA) at a wavelength of $405 \mathrm{~nm}$. The immunological activity of each tested serum was calculated by determining the $\mathrm{p}$-value (sample versus positive). In addition, the optical densities (OD) of sera were pooled at ELISA (NE) levels. The ELISA cut-off point was $21 / 2$ times the mean OD of negative reference sera (BALDANI et al., 2004; GOLYNSKI et al., 2008; MACHADO et al., 2012).

\section{Polymerase Chain Reaction (PCR)}

Ticks were collected from 17 parasitized animals (one to five ticks per animal) and subjected to PCR. The ticks were processed individually, washed with $10 \mathrm{mM}$ Tris $\mathrm{HCl}$; $1 \mathrm{mM}$ EDTA, pH 8.0 (TE), as described by Horta et al. (2007), and subjected to DNA extraction using a commercial Wizard ${ }^{\circledR}$ Genomic DNA Purification kit (Promega, Madison, USA), following the manufacturer's instructions, to a final volume of $50 \mu \mathrm{L}$. Five microliters of extracted DNA were used for PCR amplification. DNase-free water was used as a negative control 
for DNA extractions and PCR assays. PCR amplification primers of 500 base pairs of the Babesia spp. 18S rRNA gene fragment were used, as proposed by Santos et al. (2017): BAB 143-167 [5'-CCG TGC TAA TTG TAG GGCTAA TAC A-3'] e BAB 694-667 [5'-GCT TGA AAC ACT CTA RTT TCT CAA AG-3']. PCR was carried out in a total of $50 \mu \mathrm{L}$ aqueous solution containing $1 \mathrm{x}$ PCR buffer, $1.5 \mathrm{mM} \mathrm{MgCl} 2,0.2 \mathrm{mM}$ dNTPs, $1 \mathrm{U}$ of Platinum Taq DNA Polymerase (Invitrogen, Carlsbad, CA), and $0.2 \mathrm{mM}$ of each primer. The amplification procedure, which was carried out in a thermocycler $\left(\right.$ Biocycler $\left.^{\circledR}\right)$, involved the following steps: initial denaturation at $95^{\circ} \mathrm{C}$ for $5 \mathrm{~min}$, followed by 35 cycles at $95^{\circ} \mathrm{C}$ for $30 \mathrm{sec}, 58^{\circ} \mathrm{C}$ for $30 \mathrm{sec}$ and $72^{\circ} \mathrm{C}$ for $30 \mathrm{sec}$, with a final extension at $72^{\circ} \mathrm{C}$ for $7 \mathrm{~min}$. The amplification products were subjected to $1.5 \%$ agarose gel electrophoresis, stained with ethidium bromide, and examined under an ultraviolet light transducer.

\section{Statistical analysis}

The animals' owners answered an epidemiological questionnaire aimed at identifying possible risk factors associated with the presence of anti-B. caballi and anti-T. equi antibodies. The variables analyzed were age, breed, sex, presence of irrigated area, presence of ticks, degree of infestation, mucosal evaluation, use of tick repellents and uses of the animals.

The risk factor analysis was conducted in two steps: in univariate analysis, each independent variable was crossed with a dependent variable, and the ones showing a $\mathrm{p}$ value of $\leq 0.20$ by the chi-square test or Fisher's exact test were selected for multivariate analysis, using multiple logistic regression. The level of significance adopted in the multiple analysis was 5\%. All the analyses were performed using SPSS 20.0 for Windows software.

\section{Results}

Blood samples were drawn from 393 horses in rural (68.2\%) and urban areas $(31.8 \%)$, with irrigated $(67.4 \%)$ and non-irrigated areas $(32.6 \%)$. These horses comprised $65.6 \%$ males and $34.6 \%$ females; $50.4 \%$ were purebred, $8.4 \%$ were crossbreeds and $41.2 \%$ were mixed breed; $34.6 \%$ were up to 60 months old, $59.5 \%$ were 61 to 155 months old and 5.9\% were > 156 months old. The animals were used for both work (7.9\%) and recreation or sports $(92.1 \%)$. An examination of the horses' mucosa revealed that $1.8 \%$ were anemic, and $4.32 \%(17 / 393)$ had tick infestations. Among the animals with ticks, 47\% (8/17) showed mild, 35.3\% $(6 / 17)$ moderate and $17.6 \%(3 / 17)$ high infestation rates. When questioned about the use of acaricides, $20.4 \%$ of the owners confirmed that their horses were treated with such drugs.

The presence of anti-B. caballi antibodies was found in $27.2 \%$ of the horses, anti-T. equi antibodies in $34.9 \%$ and both agents in $10.7 \%$. In the univariate analysis, the variables that showed a significant association $(P<0.20)$ with the presence of anti-T. equi antibodies were purebred horses, animals older than 156 months, the presence of irrigated areas on farms, the presence of ticks, the use of tick repellent, and uses of the animals (Table 1). However, when these independent variables were subjected to multivariate analysis, the breed - category of purebred $(\mathrm{OD}=8.91, P<0.001)$,

Table 1. Risk factors associated with Theileria equi infection in horses of semiarid region of Pernambuco by univariate analysis.

\begin{tabular}{|c|c|c|c|c|}
\hline Variable & Category & Total number of horses & Number of positives (\%) & $P$ \\
\hline \multirow[t]{2}{*}{ Sex } & Female & 135 & $43(31.9)$ & \\
\hline & Male & 258 & $94(36.4)$ & 0.427 \\
\hline \multirow[t]{3}{*}{ Breed } & Purebred & 198 & $106(53.5)$ & \\
\hline & Crossbred & 33 & $8(24.2)$ & \\
\hline & No breed & 162 & $23(14.2)$ & $<0.001^{*}$ \\
\hline \multirow[t]{3}{*}{ Age } & $\leq 60$ months & 136 & $45(33.1)$ & \\
\hline & 61 to 155 months & 234 & $78(33.3)$ & \\
\hline & $\geq 156$ months & 23 & $14(60.9)$ & $0.026^{*}$ \\
\hline \multirow{2}{*}{ Mucosa } & Normal & 386 & $136(35.2)$ & \\
\hline & Anemic & 7 & $1(14.3)$ & 0.429 \\
\hline \multirow[t]{2}{*}{ Zone } & Rural & 268 & $105(39.2)$ & \\
\hline & Urban & 125 & $32(25.6)$ & $0.012^{*}$ \\
\hline \multirow[t]{2}{*}{ Irrigated area } & No & 128 & $21(16.4)$ & \\
\hline & Yes & 265 & $116(43.8)$ & $<0.001^{*}$ \\
\hline \multirow[t]{2}{*}{ Ticks } & No & 376 & $128(34.0)$ & \\
\hline & Yes & 17 & $9(52.9)$ & $0.180^{*}$ \\
\hline \multirow[t]{4}{*}{ Degree of infestation } & Null & 376 & $128(34.0)$ & \\
\hline & Mild & 8 & $4(50.0)$ & \\
\hline & Moderate & 6 & $3(50.0)$ & \\
\hline & High & 3 & $2(66.7)$ & 0.414 \\
\hline \multirow[t]{2}{*}{ Acaricide utilization } & No & 313 & $98(31.3)$ & \\
\hline & Yes & 80 & $39(48.8)$ & $0.005^{*}$ \\
\hline \multirow[t]{2}{*}{ Animal purpose } & Work & 31 & $4(12.9)$ & \\
\hline & Recreation/sports & 362 & $133(36.7)$ & $0.013^{*}$ \\
\hline
\end{tabular}

$P$ : probability of Type I error occurrence; ${ }^{*}$ Variables selected for multivariate analysis $(\mathrm{p}<0.20)$; $(\%)$ percentage. 
age - senile animals $(\mathrm{OD}=3.54, P=0.014)$ and presence of ticks (OD $=7.13, P=0.001)$ were considered risk factors for $T$. equi (Table 2). In the univariate analysis of antibodies of both agents found in the same animal, breed and the presence of irrigated areas on farms showed a significant association $(P<0.20)$ (Table 3). In the multivariate analysis, the breed - category of purebred $(\mathrm{OD}=2.61, P=0.012)$ was considered a risk factor.

No risk factors associated with the presence of anti- $B$. caballi antibodies were identified, and no intra-erythrocyte form of T. equi or B. caballi was observed in the blood smears examined under the microscope.

The OD values of cutoff points, negative control sera and positive control sera tested for $B$. caballi and T. equi were 0.351 and $0.269,0.122-0.145$ and $0.096-0.162$, and $0.948-1.175$ and $0.891-1.531$, respectively. The average OD values of samples reactive to the presence of anti-B. caballi and anti-T. equi antibodies were 0.501 and 0.615 , respectively.

One to five adult ticks were collected from each of 17 horses that were parasitized at the time of evaluation, making a total of
101 ticks, all identified as Dermacentor nitens. This tick species transmits only Babesia, so the ticks were subjected only to PCR to test for this agent. However, DNA amplification of the agents in the ticks subjected to PCR did not occur.

\section{Discussion}

The main tests used for the diagnosis of long-term equine piroplasmosis and of animals treated with antiparasitic drugs are serological tests such the indirect immunofluorescence test (IFA) and enzyme-linked immunosorbent assay (ELISA) (OIE, 2018b). A significant degree of agreement between the tests was found in a comparative study by Vieira et al. (2015). Other serological studies using these two tests also showed almost perfect agreement between them (GOLYNSKI et al., 2008; SALVAGNI et al., 2010; FARKAS et al., 2013; MAHMOUD et al., 2016). However, IFA tested an increased number of 19 horses with anti-T. equi antibodies titer in comparison with ELISA which tested only 10/19 horses with anti-T. equi antibodies titer (PIKALO et al., 2016).

Table 2. Risk factors associated with Theileria equi infection in horses of semiarid Pernambuco.

\begin{tabular}{ccc}
\hline Risk factor & Odds ratio (CI 95\%) & $\boldsymbol{P}$ \\
\hline Breed (purebred) & $8.91(5.02-15.84)$ & $<0.001$ \\
Age ( $\geq 156$ months) & $3.54(1.29-9.72)$ & 0.014 \\
Ticks (yes) & $7.13(2.29-22.17)$ & 0.001 \\
\hline
\end{tabular}

CI: confidence interval of $95 \%$; $P$ : probability of Type I error occurrence.

Table 3. Risk factors associated with Babesia caballi and Theileria equi infection in Pernambuco semiarid equines by univariate analysis.

\begin{tabular}{|c|c|c|c|c|}
\hline Variable & Category & Total number of horses & Number of positives (\%) & $P$ \\
\hline \multirow[t]{2}{*}{ Sex } & Female & 135 & $14(10.4)$ & \\
\hline & Male & 258 & $28(10.9)$ & 1.000 \\
\hline \multirow[t]{3}{*}{ Breed } & Purebred & 198 & $29(14.6)$ & \\
\hline & Crossbred & 33 & $3(9.1)$ & \\
\hline & No breed & 162 & $10(6.2)$ & $0.033^{*}$ \\
\hline \multirow[t]{3}{*}{ Age } & $\leq 60$ months & 136 & $13(9.6)$ & \\
\hline & 61 to 155 months & 234 & $28(12)$ & \\
\hline & $\geq 156$ months & 23 & $1(4.3)$ & 0.461 \\
\hline \multirow[t]{2}{*}{ Mucosa } & Normal & 386 & $42(10.9)$ & \\
\hline & Anemic & 7 & $0(0)$ & 1.000 \\
\hline \multirow[t]{2}{*}{ Zone } & Rural & 268 & $29(10.8)$ & \\
\hline & Urban & 125 & $13(10.4)$ & 1.000 \\
\hline \multirow[t]{2}{*}{ Irrigated area } & No & 128 & $8(6.3)$ & \\
\hline & Yes & 265 & $34(12.8)$ & $0.071^{*}$ \\
\hline \multirow[t]{2}{*}{ Ticks } & No & 376 & $40(10.6)$ & \\
\hline & Yes & 17 & $2(11.8)$ & 0.701 \\
\hline \multirow[t]{4}{*}{ Degree of infestation } & Null & 376 & $40(10.6)$ & \\
\hline & Mild & 8 & $1(12.5)$ & \\
\hline & Moderate & 6 & $0(0)$ & \\
\hline & High & 3 & $1(33.3)$ & 0.501 \\
\hline \multirow[t]{2}{*}{ Acaricide utilization } & No & 313 & $36(11.5)$ & \\
\hline & Yes & 80 & $6(7.5)$ & 0.406 \\
\hline \multirow[t]{2}{*}{ Animal purpose } & Work & 31 & $2(6.5)$ & \\
\hline & Recreation /sports & 362 & $40(11)$ & 0.557 \\
\hline
\end{tabular}

$P$ : probability of Type I error occurrence; *Variables selected for multivariate analysis $(\mathrm{p}<0.20)$; (\%) percentage. 
Although equine piroplasmosis is widely distributed in Brazil, there is no report of its prevalence in the state of Pernambuco. Hence, this is the first study aimed at ascertaining the seroprevalence of T. equi and B. caballi in the city of Petrolina, Pernambuco, in northeastern Brazil. The ELISA assay performed in this study revealed that, among the seroreactive horses, $34.9 \%$ tested positive for T. equi and $27.2 \%$ for B. caballi. These findings are consistent with those of two other studies conducted recently in northeastern Brazil, using ELISA, the first of which reported finding $43.5 \%$ of animals positive for T. equi and $7.7 \%$ for $B$. caballi, while the second study found $38.1 \%$ positive for T. equi and $18.6 \%$ for $B$. caballi (BRAGA et al., 2017; NOGUEIRA et al., 2017). In Paraíba, also in the country's northeastern region, a study using IFA found that $59.6 \%$ of horses were seroreactive to T. equi (FERREIRA et al., 2016). In other studies conducted in Rio Grande do Sul and the Brazilian Pantanal, $18.9 \%$ and 5.5\%, and $61.8 \%$ and $52.9 \%$, were observed seropositive horses for T. equi and B. caballi, respectively, using ELISA (VIEIRA et al., 2018; CAMPOS et al., 2019). However, the agent $B$. caballi was detected more frequently in the states of São Paulo and Mato Grosso do Sul (XUAN et al., 2001; KERBER et al., 2009). The different prevalence rates of equine piroplasmosis in the abovementioned regions may be attributed to variations in climate, equine populations studied, diagnostic tests used, and to the dynamics of tick populations (MUJICA et al., 2011; VIEIRA et al., 2013).

The test most widely used for the diagnosis of hemoparasitic diseases used to be the blood smear test, but because its low sensitivity often leads to false negatives in horses with low parasite loads, it has been replaced by indirect and direct techniques for the detection of this parasite (GOLYNSKI et al., 2008; SGORBINI et al., 2015). The results of this study are in agreement with the findings of Munkhjargal et al. (2013), who suggest that the blood smear diagnostic technique may not be suitable for epidemiological surveys of equine piroplasmosis. Moreover, Hodgson (2002) points out that this technique presents low sensitivity in cases of low parasite loads, which leads to false negative results.

The low tick infestation rate in horses on farms in the municipality of Petrolina differs from that reported in Rio de Janeiro by Santos et al. (2011), who found a moderate to severe infestation rate, i.e., $17.09 \%(122 / 702)$ by D. nitens. Climate factors such as temperature, relative air humidity, altitude and high rainfall can influence the habitat of the main tick species/vectors and define areas of enzootic instability, areas that do not favor the development of ticks throughout the year (GOLYNSKI et al., 2008). Therefore, the low infestation rate found in this study may be associated with the edaphoclimatic factors of the municipality, i.e., its location in the semi-arid region of Pernambuco, whose dry climate and low rainfall are unfavorable for the development of ticks. This suggests that the municipality is located in an area where the presence of ectoparasites in equines is low, and that such ectoparasites are found only at certain times of the year or in places with higher humidity.

PCR has been used to identify and associate some tick species with agents of equine piroplasmosis (BATTSETSEG et al., 2001, 2002; IORI et al., 2010; ABEDI et al., 2014). In this study, ticks were tested only for DNA detection of Babesia spp, since only D. nitens were found in this region. However, the presence of DNA of this agent in ticks was not detected. In contrast, Nogueira et al. (2017) collected 170 ticks from 97 horses, 151 of which were identified as D. nitens, 13 as $A$. cajennense sensu lato and 6 as Rhipicephalus microplus. Among these ticks, 2.35\% (4/170) tested positive by PCR for T. equi and $0.59 \%$ (1/170) for B. caballi.

The age of horses older than 156 months was considered a risk factor for the presence of anti-T. equi antibodies. This has also been reported by Ruegg et al. (2007), Sevinc et al. (2008) and Kouam et al. (2010), supporting the assumption that T. equi infection persists throughout life (BRÜNING, 1996). Nogueira et al. (2017) also state that the risk of T. equi infection increases as a function of age, the presence of ticks, and vaccination against other diseases.

Several of the horses evaluated here participate in sports events, which means they travel to several states and different regions. Thus, they are in contact with other animals and possibly also with the vector of $T$. equi, which may explain the presence of anti-T. equi antibodies in these animals. Transmission may also occur iatrogenically, i.e., through blood transfusions or contaminated needles (WISE et al., 2014). Kerber et al. (2009) observed that high infestations of horse flies were reported on all farms during the summer and spring months, which they would describe as a type of mechanical transmission. Cattle were present on some farms, but $R$. microplus infestations were not detected.

These factors may also be associated with purebred animals as a risk factor for T. equi. Purebred horses are more commonly used for sports and recreation activities. Some studies have been carried out solely with purebred or crossbred horses or with a specific breed predefined according to the region, since these animals are of greater economic importance in the horse market (GOLYNSKI et al., 2008; KERBER et al., 2009; GUIMARĀES et al., 2016; NUGRAHA et al., 2018). However, more specific studies are needed involving purebred and mixed breed horses in order to examine this host parasite relationship.

The identification of areas that offer a potential risk of disease transmission to horses is extremely important because it enables the implementation of adequate prophylactic measures, such as the control of vector ticks in animals and the environment, as well as the management of these animals, allied to educational actions that are essential for the prevention and control of diseases in horses.

This study confirmed, for the first time, that agents of equine piroplasmosis are circulating in the municipality of Petrolina, semi-arid region of Pernambuco, based on the indirect detection of the infection by anti-B. caballi and anti-T. equi antibodies. The municipality of Petrolina comprises an area of enzootic instability, given the low frequency of antibodies detected in its equine population, associated with the low frequency of tick infested animals. Nevertheless, additional studies in the region are needed, including studies involving purebred and mixed breed horses, in order to gain further insight into the relationship between these animals and T. equi.

\section{Acknowledgements}

This work was supported by the Brazilian funding agencies Coordenação de Aperfeiçoamento de Pessoal de Nível Superior (CAPES), Fundação de Amparo à Ciência e Tecnologia do Estado de Pernambuco (FACEPE APQ-1174-5.05/10) and Conselho Nacional de Desenvolvimento Científico e Tecnológico (CNPq) for Scientific Productivity Grant to M.C. Horta. 


\section{References}

Abedi V, Razmi G, Seifi H, Naghibi A. Molecular and serological detection of Theileria equi and Babesia caballi infection in horses and ixodid ticks in Iran. Ticks Tick Borne Dis 2014; 5(3): 239-244. http:// dx.doi.org/10.1016/j.ttbdis.2013.11.008. PMid:24556274.

Adam M, Pikalo J, Snyder A, Steinrigl A, Köller G, Schusser GF. Equine Piroplasmosis - a case of severe Babesia caballi infection associated with acute renal failure. Berl Münch Tierärztl Wochenschr 2017, 130(3-4): 113-118.

Aharonson-Raz K, Rapoport A, Hawari IM, Lensky IM, Berlin D, Zivotofsky D, et al. Novel description of force of infection and risk factors associated with Theileria equi in horses in Israel and in The Palestinian Authority. Ticks Tick Borne Dis 2014; 5(4): 366-372. http://dx.doi. org/10.1016/j.ttbdis.2014.01.002. PMid:24703834.

Aragão H, Fonseca F. Notas de Ixodologia. VIII. Lista e chave para os representantes da fauna ixodológica brasileira. Mem Inst Oswaldo Cruz 1961; 59(2): 115-129. http://dx.doi.org/10.1590/S0074-02761961000200001. PMid:13861962.

Baldani CD, Machado RZ, Botteon PTL, Takakura FS, Massard CL. An enzyme-linked immunosorbent assay for the detection of $\mathrm{IgG}$ antibodies against Babesia equi in horses. Cienc Rural 2004; 34(5): 1525-1529. http://dx.doi.org/10.1590/S0103-84782004000500031.

Baldani CD, Nakaghi AC, Machado RZ. Occurrence of Theileria equi in horses raised in the Jaboticabal microregion, São Paulo State, Brazil. Rev Bras Parasitol Vet 2010; 19(4): 228-232. http://dx.doi.org/10.1590/ S1984-29612010000400007. PMid:21184699.

Barbosa IP, Böse R, Peymann B, Friedhoff KT. Epidemiological aspects of equine babesioses in a herd of horses in Brazil. Vet Parasitol 1995; 58(1-2): 1-8. http://dx.doi.org/10.1016/0304-4017(94)00704-G. PMid:7676590.

Battsetseg B, Lucero S, Xuan X, Claveria FG, Inoue N, Alhassan A, et al. Detection of natural infection of Boophilus microplus with Babesia equi and Babesia caballi in Brazilian horses using nested polymerase chain reaction. Vet Parasitol 2002; 107(4):351-357. http://dx.doi.org/10.1016/ S0304-4017(02)00131-0. PMid:12163246.

Battsetseg B, Xuan X, Ikadai H, Bautista JLR, Byambaa B, Boldbaatar D, et al. Detection of Babesia caballi and Babesia equi in Dermacentor nuttalli adult ticks. Int J Parasitol 2001; 31(4): 384-386. http://dx.doi. org/10.1016/S0020-7519(01)00120-5. PMid:11306116.

Braga MSCO, Costa FN, Gomes DRM, Xavier DR, André MR, Gonçalves LR, et al. Genetic diversity of piroplasmids species in equids from island of São Luís, northeastern Brazil. Rev Bras Parasitol Vet 2017; 26(3): 331339. http://dx.doi.org/10.1590/s1984-29612017046. PMid:28977247.

Brüning A. Equine piroplasmosis an update on diagnosis, treatment and prevention. BrVet J 1996; 152(2): 139-151. http://dx.doi.org/10.1016/ S0007-1935(96)80070-4. PMid:8680838.

Campos JBV, André MR, Gonçalves LR, Freschi CR, Santos FM, Oliveira $\mathrm{CE}$, et al. Assessment of equine piroplasmids in the Nhecolândia sub-region of Brazilian Pantanal wetland using serological, parasitological, molecular, and hematological approaches. Ticks Tick Borne Dis 2019; 10(3): 714721. http://dx.doi.org/10.1016/j.ttbdis.2019.03.002. PMid:30876824.

de Waal DT. Equine piroplasmosis: a review. Br Vet J 1992; 148(1): 6-14. http://dx.doi.org/10.1016/0007-1935(92)90061-5. PMid:1551016.

Farkas R, Tánczos B, Gyurkovszky M, Földvári G, Solymosi N, Edelhofer $\mathrm{R}$, et al. Serological and molecular detection of Theileria equi infection in horses in Hungary. Vet Parasitol 2013; 192(1-3): 143-148. http://dx.doi. org/10.1016/j.vetpar.2012.09.035. PMid:23099089.

Ferreira EP, Vidotto O, Almeida JC, Ribeiro LPS, Borges MV, Pequeno WHC, et al. Serological and molecular detection of Theileria equi in sport horses of northeastern Brazil. Comp Immunol Microbiol Infect Dis 2016; 47: 72-76. http://dx.doi.org/10.1016/j.cimid.2016.06.004. PMid:27477509.

Golynski AA, Fernandes KR, Baldani CD, Golynski AL, Madeiro AS, Machado RZ, et al. Estudo soroepidemiológico da Babesia equi em equinos do Estado do Rio Grande do Sul, Brasil, determinado pelos testes de imunofluorescência indireta e ELISA. Rev Bras Parasitol Vet 2008; 17(Suppl Supl.1): 317-321. PMid:20059868.

Guimarães AM, Bruhn FRP, Ribeiro MJM, Rosa MHF, Garcia AM, Rocha CMBM, et al. Prevalence and risk factors of Theileria equi infection in horses in Minas Gerais, Brazil. Vet Parasitol Reg Stud Rep 2016; 3-4: 18-22. http://dx.doi.org/10.1016/j.vprsr.2016.05.005. PMid:31014494.

Guimarães AM, Lima JD, Ribeiro MFB. Sporogony and experimental transmission of Babesia equi by Boophilus microplus. Parasitol Res 1998; 84(4): 323-327. http://dx.doi.org/10.1007/s004360050404. PMid:9580425.

Heim A, Passos LM, Ribeiro MF, Costa LM Jr, Bastos CV, Cabral $\mathrm{DD}$, et al. Detection and molecular characterization of Babesia caballi and Theileria equi isolates from endemic areas of Brazil. Parasitol Res 2007; 102(1): 63-68. http://dx.doi.org/10.1007/s00436-007-0726-1. PMid:17828553.

Heuchert CM, Giulli V Jr, Athaide DF, Bose R, Friedhoff KT. Seroepidemiologic studies on Babesia equi and Babesia caballi infections in Brazil. Vet Parasitol 1999; 85(1): 1-11. http://dx.doi.org/10.1016/ S0304-4017(99)00108-9. PMid:10447188.

Hodgson J. Equine exotic diseases, a manual for horse owners. Canberra: Union Offset; 2002. RIRDC: Publication No. 02/054.

Horta MC, Labruna MB, Pinter A, Linardi PM, Schumaker TTS. Rickettsia infection in five areas of the state of São Paulo, Brazil. Mem Inst Oswaldo Cruz 2007; 102(7): 793-801. http://dx.doi.org/10.1590/ S0074-02762007000700003. PMid:18094887.

Iori A, Gabrielli S, Calderini P, Moretti A, Pietrobelli M, Tampieri MP, et al. Tick reservoirs for piroplasms in central and northern Italy. Vet Parasitol 2010; 170(3-4): 291-296. http://dx.doi.org/10.1016/j. vetpar.2010.02.027. PMid:20304560.

Kappmeyer LS, Thiagarajan M, Herndon DR, Ramsay JD, Caler E, Djikeng A, et al. Comparative genomic analysis and phylogenetic position of Theileria equi. BMC Genomics 2012; 13(1): 603. http:// dx.doi.org/10.1186/1471-2164-13-603. PMid:23137308.

Kerber CE, Ferreira F, Pereira MC. Control of equine piroplasmosis in Brazil. Onderstepoort J Vet Res 1999; 66(2): 123-127. PMid:10486829.

Kerber CE, Labruna MB, Ferreira F, de Waal DT, Knowles DP, Gennari SM. Prevalence of equine piroplasmosis and its association with tick infestation in the State of São Paulo, Brazil. Rev Bras Parasitol Vet 2009; 18(4): 1-8. http://dx.doi.org/10.4322/rbpv.01804001. PMid:20040201.

Kouam MK, Kantzoura V, Gajadhar AA, Theis JH, Papadopoulos E, Theodoropoulos G. Seroprevalence of equine piroplasms and hostrelated factors associated with infection in Greece. Vet Parasitol 2010; 169(3-4): 273-278. http://dx.doi.org/10.1016/j.vetpar.2010.01.011. PMid:20138434.

Machado RZ, Toledo CZP, Teixeira MCA, André MR, Freschi CR, Sampaio PH. Molecular and serological detection of Theileria equi and 
Babesia caballi in donkeys (Equus asinus) in Brazil. Vet Parasitol 2012; 186(3-4): 461-465. http://dx.doi.org/10.1016/j.vetpar.2011.11.069. PMid:22186194.

Mahmoud MS, El-Ezz NTA, Abdel-Shafy S, Nassar SA, El Namaky $\mathrm{AH}, \mathrm{Khalil}$ WKB, et al. Assessment of Theileria equi and Babesia caballi infections in equine populations in Egypt by molecular, serological and hematological approaches. Parasit Vectors 2016; 9(1): 260. http://dx.doi. org/10.1186/s13071-016-1539-9. PMid:27146413.

Mehlhorn H, Schein E. Redescription of Babesia equi Laveran, 1901 as Theileria equi, Mehlhorn, Schein 1998. Parasitol Res 1998; 84(6): 467-475. http://dx.doi.org/10.1007/s004360050431. PMid:9660136.

Mujica FF, Perrone T, Forlano M, Coronado A, Meléndez RD, Barrios $\mathrm{N}$, et al. Serological prevalence of Babesia caballi and Theileria equi in horses of Lara State, Venezuela. Vet Parasitol 2011; 178(1-2): 180-183. http://dx.doi.org/10.1016/j.vetpar.2010.12.036. PMid:21273001.

Munkhjargal T, Sivakumar T, Battsetseg B, Nyamjargal T, Aboulaila M, Purevtseren B, et al. Prevalence and genetic diversity of equine piroplasms in Tov province, Mongolia. Infect Genet Evol 2013; 16: 178-185. http:// dx.doi.org/10.1016/j.meegid.2013.02.005. PMid:23416256.

Nogueira RMS, Silva AB, Sato TP, Sá JC, Santos ACG, Amorim EF Fo, et al. Molecular and serological detection of Theileria equi, Babesia caballi and Anaplasma phagocytophilum in horses and ticks in Maranhão, Brazil. Pesq Vet Bras 2017; 37(12): 1416-1422. http://dx.doi.org/10.1590/ s0100-736x2017001200010.

Nugraha AB, Cahyaningsih U, Amrozi A, Ridwan Y, Agungpriyono $S$, Taher DM, et al. Serological and molecular prevalence of equine piroplasmosis in Western Java, Indonesia. Vet Parasitol Reg Stud Rep 2018; 14: 1-6. http://dx.doi.org/10.1016/j.vprsr.2018.07.009. PMid:31014711.

Pikalo J, Sattler T, Eichinger M, Loitsch A, Schmoll F, Schusser GF. Seroprevalence of Babesia caballi and Theileria equi in horses in Central Germany. Pferdeheilkunde 2016; 32(3): 254-259. http://dx.doi. org/10.21836/PEM20160309.

Prochno HC, Scorsin LM, Melo FR, Baldani CD, Falbo MK, Aquino LCT, et al. Seroprevalence rates of antibodies against Theileria equi in team roping horses from central-western region of Paraná. Rev Bras Parasitol Vet 2014; 23(1): 85-89. http://dx.doi.org/10.1590/S198429612014012 . PMid:24728366.

Ribeiro MFB, Costa JO, Guimarães AM. Epidemiological aspects of Babesia equi in horses in Minas Gerais, Brazil. Vet Res Commun 1999; 23(6): 385-390. http://dx.doi.org/10.1023/A:1006389725759. PMid:10543367.

Ruegg SR, Torgerson P, Deplazes P, Mathis A. Age-dependent dynamics of Theileria equi and Babesia caballi infections in southwest Mongolia based on IFAT and/or PCR prevalence data from domestic horses and ticks. Parasitol 2007; 134(Pt 7): 939-947. http://dx.doi.org/10.1017/ S0031182007002405. PMid:17306055.

Salvagni CA, Dagnone AS, Gomes TS, Mota JS, Andrade GM, Baldani $\mathrm{CD}$, et al. Serologic evidence of equine granulocytic anaplasmosis in horses from central West Brazil. Rev Bras Parasitol Vet 2010; 19(3): 135-140. http://dx.doi.org/10.1590/S1984-29612010000300002. PMid:20943015.

Santos GB, Gomes IMM, Silveira JAG, Pires LCSR, Azevedo SS, Antonelli AC, et al. Tristeza Parasitária em bovinos do semiárido pernambucano. Pesq Vet Bras 2017; 37(1): 1-7. http://dx.doi.org/10.1590/ s0100-736x2017000100001.

Santos TM, Roier ECR, Santos HA, Pires MS, Vilela JAR, Moraes $\mathrm{LMB}$, et al. Factors associated to Theileria equi in equids of two microregions from Rio de Janeiro, Brazil. Rev Bras Parasitol Vet 2011; 20(3): 235-241. http://dx.doi.org/10.1590/S1984-29612011000300011. PMid:21961755.

Santos TM, Santos HA, Massard CL. Diagnóstico molecular de babesiose congénita em potros neonatos no estado do Rio de Janeiro, Brasil. Rev Bras Parasitol Vet 2008; 17(Suppl Supl. 1): 348-350. PMid:20059877.

Schein FB, Maia MO, Witter R, Marcili A, Camargo LM, Dutra V, et al. Molecular survey and genetic diversity of piroplasmids in equids from Midwestern Brazil. Braz J Vet Parasitol 2018; 27(4): 464-472. http:// dx.doi.org/10.1590/s1984-296120180048. PMid:30183997.

Sevinc F, Maden M, Kumas C, Sevinc M, Ekici OD. A comparative study on the prevalence of Theileria equi and Babesia caballi infections in horse sub-populations in Turkey. Vet Parasitol 2008; 156(3-4): 173177. http://dx.doi.org/10.1016/j.vetpar.2008.06.006. PMid:18672330.

Sgorbini M, Bonelli F, Nardoni S, Rocchigiani G, Corazza M, Mancianti F. Seroprevalence and molecular analysis of Babesia caballi and Theileria equi in horses from central Italy during a 10-year period. J Eq Vet Sci 2015; 35(10): 865-868. http://dx.doi.org/10.1016/j.jevs.2015.08.011.

Tenter AM, Friedhoff KT. Serodiagnosis of experimental and natural Babesia equi and B. caballi infections. Vet Parasitol 1986; 20(1-3): 49-61. http://dx.doi.org/10.1016/0304-4017(86)90092-0. PMid:3518217.

Vieira MIB, Costa MM, Oliveira MT, Gonçalves LR, André MR, Machado RZ. Serological detection and molecular characterization of piroplasmids in equids in Brazil. Acta Trop 2018; 179: 81-87. http:// dx.doi.org/10.1016/j.actatropica.2017.12.028. PMid:29291385.

Vieira TSWJ, Valente JDM, Silva NB, Sicupira PML, Barros-Filho IR, Biondo AW, et al. Comparative study of two serological tests for detection of anti- Theileria equi antibodies in horses. Semina: Ciênc Agrár 2015; 36(2): 4361-4364. http://dx.doi.org/10.5433/16790359.2015 v36n6Supl2p4361.

Vieira TSWJ, Vieira RFC, Finger MAP, Nascimento DAG, Sicupira PML, Dutra LH, et al. Seroepidemiological survey of Theileria equi and Babesia caballi in horses from a rural and from urban areas of Paraná State, southern Brazil. Ticks Tick Borne Dis 2013; 4(6): 537-541. http:// dx.doi.org/10.1016/j.ttbdis.2013.07.005. PMid:24209493.

Wise LN, Kappmeyer LS, Mealey RH, Knowles DP. Review of equine piroplasmosis. J Vet Intern Med 2013; 27(6): 1334-1346. http://dx.doi. org/10.1111/jvim.12168. PMid:24033559.

Wise LN, Pelzel-McCluskey AM, Mealey RH, Knowles DP. Equine Piroplasmosis. Vet Clin N Am-Equine 2014; 30(3): 677-693. http:// dx.doi.org/10.1016/j.cveq.2014.08.008. PMid:25300637.

World Organisation for Animal Health - OIE. Chapter 12.7: equine piroplasmosis [online]. In: World Organisation for Animal Health - OIE. Terrestrial Manual Health Code. Paris: OIE; 2018a [cited 2019 May 29]. Available from: http://www.oie.int/fileadmin/Home/eng/Health_standards/ tahc/current/chapitre_equine_piroplasmosis.pdf

World Organisation for Animal Health - OIE. Chapter 3.5.8: equine piroplasmosis [online]. In: World Organisation for Animal Health - OIE. Terrestrial Manual Health Code. Paris: OIE; 2018b [cited 2019 May 29]. Available from: http://www.oie.int/fileadmin/Home/eng/Health_standards/ tahm/3.05.08_EQUINE_PIROPLASMOSIS.pdf

Xuan X, Nagai A, Battsetseg B, Fukumoto S, Makala LH, Inoue N, et al. Diagnosis of equine piroplasmosis in Brazil by serodiagnostic methods with recombinant antigens. J Vet Med Sci 2001; 63(10): 1159-1160. http://dx.doi.org/10.1292/jvms.63.1159. PMid:11714038. 